\title{
EFFECT OF FREE-RANGE AREA AND FEED RESTRICTION ON GROWTH PERFORMANCE OF HUNGARIAN LANDRACE GUINEA FOWL
}

Thieu Ngoc Lan Phuong ${ }^{1}$, Timea Roza Ferencz ${ }^{2}$, Katalin Kovacsne Gaal ${ }^{3}$, Ildiko Barta ${ }^{4}$, Kisne Do Thi Dong Xuan ${ }^{5}$, Andrea Emodi ${ }^{6}$, Szalay István ${ }^{7}$

\begin{abstract}
Hungarian Landrace Guinea Fowls are famous for their excellent meat quality produced by traditional free-range farming. The study aimed to identify the optimal size of a free-range area for keeping Hungarian Landrace Guinea Fowl, and to examine its effect in combination with quantitative feed restriction on growth performance, 486 birds were randomly distributed into 18 cages. Free-range areas of different sizes (either $50 \mathrm{~m}^{2}$ or $15 \mathrm{~m}^{2}$ per bird, or without a running area) were provided from 6 weeks of age, and from 9 to 14 weeks, feed restriction at varying levels of $90 \%$, $80 \%, 70 \%$ or ad libitum feeding was also applied. Body weight, body weight gain and feed conversion ratios were recorded every two weeks. Results showed that differing freerange area sizes and feed restriction had a substantial effect on the body weight of Hungarian Landrace Guinea Fowl, which was evident by the age of 10 weeks and continued until 14 weeks, where feed restriction negatively affected guinea fowl growth in free-range keeping. Guinea fowl provided with $15 \mathrm{~m}^{2}$ of free-range area per bird and fed ad libitum had the highest body weight
\end{abstract}

\footnotetext{
${ }^{1,4,6}$ Research Centre for Farm Animal Gene Conservation (HáGK), H-2100 Gödöllő, Isaszegi út 200., Hungary; Association for Hungarian Farm Animal Gene Conservation (MGE), H-2100 Gödöllő, Isaszegi út 208., Hungary

${ }^{2,3}$ Szechenyi Istvan University, Faculty of Agricultural and Food Sciences (SZE-MEK), Var 2, H-9200, Mosonmagyaróvár, Hungary; Association for Hungarian Farm Animal Gene Conservation (MGE), H-2100 Gödöllő, Isaszegi út 208., Hungary

${ }^{5,7}$ Association for Hungarian Farm Animal Gene Conservation (MGE), H-2100 Gödöllő, Isaszegi út 208., Hungary

Email: lanphuong@hagk.hu

Received date: $10^{\text {th }}$ May 2019; Revised date: $04^{\text {th }}$ June 2019; Accepted date: $30^{\text {th }}$ July 2019
}

$(1378.52 \pm 43.68 \mathrm{~g})$ with relatively low feed conversion ratio $(3.82 \pm 0.14 \mathrm{~kg}$ feed per $\mathrm{kg}$ body weight gain) when compared with other experimental groups at the age of 14 weeks. The lowest body weight and feed conversion ratio was observed in groups with $15 \mathrm{~m}^{2}$ freerange area per bird and $70 \%$ feed restriction $(1245.93 \pm 38.64 \mathrm{~g}$ and $3.52 \pm 0.12 \mathrm{~kg}$ feed per $\mathrm{kg}$ body weight gain), while the highest feed conversion ratio was detected in groups fed ad libitum and kept closed, without a free range area $(4.34 \pm 0.06 \mathrm{~kg}$ feed per $\mathrm{kg}$ body weight gain).

Keywords: conservation, free-range, and local guinea fowl.

\section{INTRODUCTION}

There is evidence that guinea fowl had been introduced into the Carpathian Basin several centuries earlier than the first reports of the breeding of this animal appeared, and was kept as a pet around manor houses or monasteries from the Middle Ages [1], [2], thereafter a long adaptation process resulted in local landrace varieties. However, with the expansion of the poultry industry, local landraces have begun to disappear gradually from rural areas. The collection of local guinea fowl individuals from various rural regions in Hungary for conservation purposes was initiated in the early 1990's. The breed was officially registered under the name of Hungarian Landrace Guinea Fowl (HLGF) in 2004 by the Association of Hungarian Small Animal Breeders for Gene Conservation (MGE). Since then, unselected stocks of HLGF have been kept as part of in vivo gene bank at the Research Centre for Farm Animal Gene Conservation (HáGK) and Hortobagy 
National Park (HNP) [3]. Several studies emphasize that local guinea fowl would be one of the promising genetic resources for evolving in low input systems which can be seen from the popularity of keeping guinea fowl in underprivileged regions of Africa [4], [5], Central Europe an countries [6]-[8] as well as in Southeast Asia [9]. Scientists consider guinea fowl as a reliable contributor to the livelihood of rural people [10], [11], and therefore, has the potential for reducing poverty [12]. Because of this, studies on the improvement of guinea fowl productivity, as well as investigation into the effects of genetic potential on productive and reproductive traits of local varieties for future use in various regions, are essential.

\section{BACKGROUND}

Hungarian poultry experts in the 20th century, Zoltan Csukas (1935) and Balint Baldy (1940), mentioned that excellent meat quality, good adaptability, disease resistance, and low keeping costs made guinea fowl an excellent poultry species - not only for local consumption but also for foreign markets. To ensure these superior traits are kept during farming practices, there is emphasis placed on the fact that guinea fowl should be kept using traditional methods as a scavenging bird around houses or large free-range farms [13], [14]. These traditional methods were characteristic for local guinea fowl raising in Hungary before the expansion of the poultry industry and can be considered as 'traditional free-range farming'. Regarding nutritional regimes, Molapo and Webb [15] found that quantitative restriction of feeding applied as part of the rearing system could be advantageous in body weight gain of local chickens, which can be applicable seeing that guinea fowl chicks at growing stages have the same nutritional behaviour as chickens, thus restricted feeding may be useful for improving their growth performance [16]. However the effect of restricted feeding on production in guinea fowl remains uncertain. This study aims to identify an optimal size of a free-range area for keeping HLGF using traditional methods and examines the effect of qualitative feed restriction on the growth performance of HLGF.

\section{MATERIALS AND METHODS}

\section{A. Experimental design}

This study took place at the HáGK in vivo poultry gene bank farm in Gödöllő, Hungary. A base population of 486 birds were hatched from the nucleus stock of the HLGF gene bank. All chicks were marked with individual wing bands, then at birth, males and females were pooled together for investigation. In the first 5 weeks, the birds were kept in an enclosed area with a density of 40 birds per $\mathrm{m} 2$ and fed ad libitum. From 6 weeks of age, all 486 birds were moved to a house for growers with free-range areas of different sizes (either $50 \mathrm{~m} 2$ or $15 \mathrm{~m} 2$ per bird) or without a running area, and were randomly distributed into 18 cages (27 birds per cage, 9 birds per m2). From 9 to 14 weeks of age, different feeding regimes (feed restriction at the levels of $90 \%, 80 \%, 70 \%$ and ad libitum feeding) were applied. The experimental design of the HLGF rearing system, and the labels of treatments are shown in Table 1.

Quantitative feed restrictions were applied through the control of the daily feed supply. From 9 to 14 weeks of age, the amount of feed given (FG) in the restricted feeding regimes was calculated based on measured feed intake (FI) of the ad libitum group from the previous week.

Equations used for the calculation of FG at 9 weeks of age were:

FG of $15 \mathrm{R} 90$ in $\mathrm{i}^{\text {th }}$ week $=90 \% \times$ FI of $15 \mathrm{Adl}$ in $\mathrm{j}^{\text {th }}$ week FG of 15R80 in $\mathrm{i}^{\text {th }}$ week $=80 \% \times$ FI of $15 \mathrm{Adl}$ in $\mathrm{j}^{\text {th }}$ week FG of $15 \mathrm{R} 70$ in $\mathrm{i}^{\text {th }}$ week $=70 \% \times$ FI of $15 \mathrm{Adl}$ in $\mathrm{j}^{\text {th }}$ week

Where: $\mathrm{j}=$ a previous week $(\mathrm{j}=8,9,10$, 11,12 and 13); and $\mathrm{i}=\mathrm{j}+1$ week $(\mathrm{i}=9,10$, $11,12,13$ and 14)

The feed that was supplied was the feed prescribed by Szalay et al. [6] was given to all groups. The survival rate, body weight (BW), 
Table 1: Experimental arrangement of Hungarian Landrace Guinea Fowl rearing systems from 6 to 8 and from 9 to 14 weeks of age

\begin{tabular}{|c|c|c|c|}
\hline Label & Birds $x$ cages & 6-8 weeks of age & 9-14 weeks of age \\
\hline 50Adl & $27 \times 3$ & $50 \mathrm{~m}^{2}$ free-range area per bird ad libitum feeding & $50 \mathrm{~m}^{2}$ free-range area per bird ad libitum feeding \\
\hline 00Adl & $27 \times 3$ & No free-range area per bird ad libitum feeding & No free-range area per bird ad libitum feeding \\
\hline $15 \mathrm{Adl}$ & $27 \times 3$ & $15 \mathrm{~m}^{2}$ free-range area per bird ad libitum feeding & $15 \mathrm{~m}^{2}$ free-range area per bird ad libitum feeding \\
\hline $15 \mathrm{R} 90$ & $27 \times 3$ & $15 \mathrm{~m}^{2}$ free-range area per bird ad libitum feeding & $\begin{array}{c}15 \mathrm{~m}^{2} \text { free-range area per bird restricted feeding } \\
\text { at } 90 \%\end{array}$ \\
\hline $15 \mathrm{R} 80$ & $27 \times 3$ & $15 \mathrm{~m}^{2}$ free-ranging area per bird ad libitum feeding & $\begin{array}{c}15 \mathrm{~m}^{2} \text { free-range area per bird restricted feeding } \\
\text { at } 80 \%\end{array}$ \\
\hline $15 \mathrm{R} 70$ & $27 \times 3$ & $15 \mathrm{~m}^{2}$ free-ranging area per bird ad libitum feeding & $\begin{array}{c}15 \mathrm{~m}^{2} \text { free-range area per bird restricted feeding } \\
\text { at } 70 \%\end{array}$ \\
\hline
\end{tabular}

body weight gain (BWG) and feed conversion ratio (FCR, kg feed per kg body weight gain) of HLGF was recorded at birth, 5 weeks of age and every two weeks from the $6^{\text {th }}$ week. Experimental birds were tested in compliance with the national laws and regulations of HáGK.

\section{B. Data analysis}

All statistical tests were performed by SPSS software version 20 [17], mean and standard deviation was estimated. Data was subjected first to Levene's test for homogeneity, then one-way ANOVA (for the $6^{\text {th }}$ and $8^{\text {th }}$ week) and two-way ANOVA test (weeks 10, 12 and 14). Following ANOVA, a pairwise comparison was conducted by Tukey test.

\section{RESULTS AND DISCUSSION}

This study showed that the survival rate of guinea fowl kept in all investigated systems was relatively high. From six to fourteen weeks of age, the lowest recorded survival rate was $96.3 \%$ with no significant difference amongst groups. The average BW and FCR of HLGF were comparable to the results observed in studies of Blum et al. [18] and Adjetey et al. [19]. HLGF seemed to become more sensitive to the sizes of the free-range area and feeding regimes as they aged. Average BW measured on the hatching day and at the end of the $5^{\text {th }}$ week was $29 \mathrm{~g}$ and 287 $\mathrm{g}$ respectively. Following the application of different sizes of free-range areas and feeding regimes, the average BW and FCR recorded at the ages of weeks 6,8 and weeks 10,12 , 14 are shown in Tables 2 and 3 . Figure 1 illustrates BWG of HLGF in the period between 8 to 14 weeks of age. The results of Levene's test indicated that equality of variances could be assumed. The size of the free-range area did not affect BW, FCR of HLGF between the $6^{\text {th }}$ and $8^{\text {th }}$ week. The significant impact of free-range area size on BW was found at the age of 10 weeks and on FCR at the age of 10,12 and 14 weeks and it had a substantial effect on the BWG of HLGF at all ages. While the effect of feed restriction on BW and BWG was apparent, it was hardly seen to affect FCR.

The results showed that BW and BWG of birds with feed restriction were significantly lower than birds fed ad libitum. The higher rate of feed restriction was applied, the lower BWG was recorded. From 8 to 14 weeks of age, the 15Adl experimental group gained $634.07 \pm 41.95 \mathrm{~g}$ and grew $1.47 \pm$ $0.09 \%$ per day. This result was comparable to that of $15 \mathrm{R} 90$ but significantly higher than 
Table 2: Average body weight (BW, g) and feed conversion ratio (FCR, $\mathrm{kg}$ feed per $\mathrm{kg}$ body weight gain) of Hungarian Landrace Guinea Fowl, kept with different free-range area sizes, and recorded on weeks 6 and 8 .

\begin{tabular}{|c|c|c|c|c|c|c|c|}
\hline & \multirow{2}{*}{$\frac{50 \mathrm{~m}^{2} \text { per bird }}{50 \mathrm{Adl}}$} & \multicolumn{4}{|c|}{$15 m^{2}$ per bird } & \multirow{2}{*}{$\begin{array}{c}\text { No free-range area } \\
\text { 00Adl }\end{array}$} & \multirow{3}{*}{ Sig } \\
\hline & & 15Adl & 15R90 & $15 R 80$ & $15 R 70$ & & \\
\hline & Mean \pm SD & Mean \pm SD & Mean \pm SD & Mean \pm SD & Mean \pm SD & Mean \pm SD & \\
\hline BW6 & $570.37 \pm 7.14$ & $554.07 \pm 31.77$ & $556.30 \pm 7.80$ & $568.15 \pm 34.02$ & $551.85 \pm 13.39$ & $576.30 \pm 26.04$ & ns \\
\hline BW8 & $778.52 \pm 11.18$ & $744.44 \pm 23.09$ & $765.19 \pm 7.80$ & $751.85 \pm 39.90$ & $746.67 \pm 21.43$ & $740.74 \pm 24.48$ & ns \\
\hline FCR6 & $2.60 \pm 0.03$ & $2.55 \pm 0.17$ & $2.58 \pm 0.02$ & $2.46 \pm 0.15$ & $2.50 \pm 0.09$ & $2.45 \pm 0.12$ & \\
\hline FCR8 & $3.02 \pm 0.04$ & $3.04 \pm 0.11$ & $3.06 \pm 0.02$ & $2.98 \pm 0.16$ & $2.96 \pm 0.10$ & $3.09 \pm 0.11$ & \\
\hline
\end{tabular}

SD: standard deviation; Sig.: significance detected by ANOVA test, ns: not significant; 50Adl: free-range area of $50 \mathrm{~m}^{2}$ per bird and ad libitum feeding from $8^{\text {th }}$ to 14 weeks; $15 \mathrm{Adl}$ : free-range area of $15 \mathrm{~m}^{2}$ per bird and ad libitum feeding from $8^{\text {th }}$ to 14 weeks; OOAdl: no free-range area and ad libitum feeding from $8^{\text {th }}$ to 14 weeks; 15R90: free-range area of $15 \mathrm{~m}^{2}$ per bird and $90 \%$ feed restriction from $8^{\text {th }}$ to 14 weeks; 15R80: free-range area of $15 \mathrm{~m}^{2}$ per bird and $80 \%$ feed restriction from $8^{\text {th }}$ to 14 weeks; 15R70: free-range area of $15 \mathrm{~m}^{2}$ per bird and $70 \%$ feed restriction from $8^{\text {th }}$ to 14 weeks

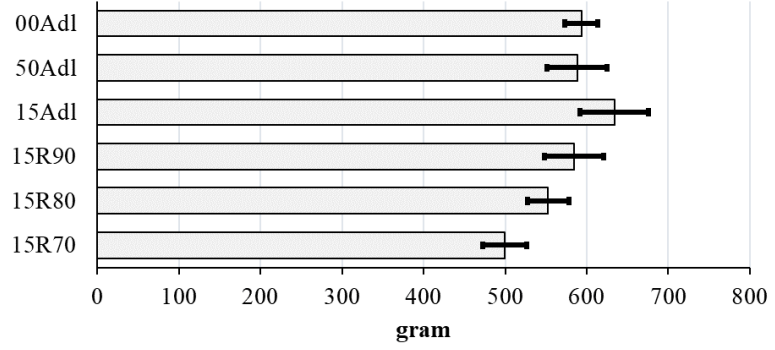

Fig. 1: Bodyweight gain of Hungarian Landrace Guinea Fowl in the period between 8 weeks to 14 weeks of age (50Adl: freerange area of $50 \mathrm{~m}^{2} /$ bird and ad libitum feeding;15Adl: free-range area of $15 \mathrm{~m}^{2} /$ bird and ad libitum feeding;00Adl: no free-range area and ad libitum feeding; 15R90: free-range area of $15 \mathrm{~m}^{2} /$ bird and $90 \%$ feed restriction; 15R80: free-range area of $15 \mathrm{~m}^{2} /$ bird and $80 \%$ feed restriction; 15R70: free-range area of $15 \mathrm{~m}^{2} /$ bird and $70 \%$ feed restriction)

recorded in both $15 \mathrm{~F} 80$ and $15 \mathrm{R} 70$ groups. Additionally, at the age of 14 weeks, 15Adl had the highest BW and relatively low FCR in comparison with others. The lowest BW and FCR were obtained by 15R70, while the highest FCR was detected in 00Adl. The results demonstrate that if feed quantity was restricted, guinea fowl would grow slower, even though there is access to large running areas (up to $50 \mathrm{~m}^{2} / \mathrm{bird}$ ).

Based on the observations, approximately $15 \mathrm{~m}^{2}$ of free-range area and ad libitum feeding are recommended to keep local landrace guinea fowl for meat production, up to 14 weeks of age. This sizeable running area is in accordance with the traditional free-range farming mentioned by Baldy (1940), being almost 4 times higher than present organic farming regulation for guinea fowl.

\section{CONCLUSION}

The size of the free-range area coupled with feed restriction techniques had a significant effect on the body weight of Hungarian Landrace Guinea Fowl only after 8 weeks, and predominantly from the age of 10 to 14 weeks. Feed restriction was found to negatively affect guinea fowl growth, therefore a free-range area of $15 \mathrm{~m}^{2}$ per bird with ad libitum feeding is recommended for optimal meat production of Hungarian Landrace Guinea Fowl. 
Table 3: Average body weight (BW, g) and feed conversion ratio (FCR, kg feed per kg body weight gain) of Hungarian Landrace Guinea Fowl, kept with different free-range area sizes and feed restriction regimes, and recorded on weeks 10, 12 and 14.

\begin{tabular}{|c|c|c|c|c|c|c|c|c|c|}
\hline & 50Adl & 15Adl & 00Adl & \multirow{2}{*}{ Sig. } & 15Adl & $15 R 90$ & 15R80 & $15 R 70$ & \multirow{2}{*}{ Sig. } \\
\hline & Mean \pm SD & Mean \pm SD & Mean \pm SD & & Mean \pm SD & Mean \pm SD & Mean \pm SD & $\begin{array}{l}\text { Mean } \\
\pm \text { SD }\end{array}$ & \\
\hline \multirow{2}{*}{ BW10 } & & $998.52^{a b}$ & $983.70^{b}$ & \multirow[t]{2}{*}{$*$} & & $942.96^{a}$ & $926.67^{b}$ & $888.15^{c}$ & \multirow[t]{2}{*}{$* *$} \\
\hline & \pm 5.13 & \pm 4.63 & \pm 13.02 & & \pm 4.63 & \pm 7.14 & \pm 31.11 & \pm 14.80 & \\
\hline \multirow[t]{2}{*}{ BW12 } & & 1224.44 & & \multirow[t]{2}{*}{ ns } & $1224.44^{a}$ & $1161.48^{a}$ & $1088.89^{a b}$ & $1048.89^{b}$ & \multirow[t]{2}{*}{$* *$} \\
\hline & \pm 33.55 & \pm 50.88 & \pm 43.11 & & \pm 50.88 & \pm 21.00 & \pm 30.55 & \pm 40.06 & \\
\hline \multirow{2}{*}{ BW14 } & & 1378.52 & 1334.07 & \multirow{2}{*}{ ns } & $1378.52^{a}$ & $1349.63^{a}$ & $1304.44^{b}$ & $1245.93^{c}$ & \multirow[t]{2}{*}{$*$} \\
\hline & \pm 40.00 & \pm 43.68 & \pm 40.04 & & \pm 43.68 & \pm 38.25 & \pm 38.55 & \pm 38.64 & \\
\hline \multirow[t]{2}{*}{ FCR10 } & $3.11^{b}$ & $3.15^{b}$ & $3.36^{a}$ & \multirow[t]{2}{*}{$* *$} & 3.15 & 3.34 & 3.20 & 3.19 & \multirow[t]{2}{*}{ ns } \\
\hline & \pm 0.01 & \pm 0.02 & \pm 0.05 & & \pm 0.02 & \pm 0.01 & \pm 0.11 & \pm 0.06 & \\
\hline \multirow[t]{2}{*}{ FCR12 } & $3.35^{b}$ & $3.41^{b}$ & $3.76^{a}$ & \multirow[t]{2}{*}{$* *$} & 3.41 & 3.50 & 3.46 & 3.38 & \multirow[t]{2}{*}{ ns } \\
\hline & \pm 0.07 & \pm 0.02 & \pm 0.12 & & \pm 0.02 & \pm 0.06 & \pm 0.11 & \pm 0.14 & \\
\hline \multirow{2}{*}{ FCR14 } & $3.76^{b}$ & $3.82^{b}$ & $4.34^{a}$ & \multirow{2}{*}{$* *$} & $3.82^{a}$ & $3.83^{a}$ & $3.63^{b}$ & $3.52^{c}$ & \multirow{2}{*}{$* *$} \\
\hline & \pm 0.12 & \pm 0.14 & \pm 0.06 & & \pm 0.14 & \pm 0.11 & \pm 0.12 & \pm 0.12 & \\
\hline
\end{tabular}

${ }^{a},{ }^{b},{ }^{c}$ : different superscript letters in a column show significant differences $(P<0.05)$ between groups, analysed by Tukey HSD test; SD: standard deviation; Sig.: significance detected by ANOVA test, ns: not significant, *: $P<0.05$; **: $P<0.01 ; 50 \mathrm{Adl}$ : free-range area of $50 \mathrm{~m}^{2}$ per bird and ad libitum feeding from $8^{\text {th }}$ to 14 weeks ; 15Adl: free-range area of $15 \mathrm{~m}^{2}$ per bird and ad libitum feeding from $8^{\text {th }}$ to 14 weeks; OOAdl: no free-range area and ad libitum feeding from $8^{\text {th }}$ to 14 weeks; 15R90: free-range area of $15 \mathrm{~m}^{2}$ per bird and $90 \%$ feed restriction from $8^{\text {th }}$ to 14 weeks; 15R80: free-range area of $15 \mathrm{~m}^{2} \mathrm{per}$ bird and $80 \%$ feed restriction from $8^{\text {th }}$ to 14 weeks; 15R70: free-range area of $15 \mathrm{~m}^{2}$ per bird and $70 \%$ feed restriction from $8^{\text {th }}$ to 14 weeks

\section{REFERENCES}

[1] Rodiczky J. Review of all poultry breeding branches. In: Pallas Reszvenytarsasag Nyomdaja. Budapest. FAO UN; 1902. .

[2] Krenedits O. Poultry breeding. In: Athenaeum Irodalmi es Nyomdai Rt., Budapest. FAO UN; 1920.

[3] Szalay IT, Lan Phuong TN, Ferencz TR, Dong Xuan KDT, Kustos K, Kovacsne Gaal K. Assessing meat production of 3 Hungarian Landrace Guinea Fowl ecotypes reserved for in vivo conservation. Journal of Applied Poultry Research. 2016;25:139144.

[4] Agbolosu AA, Teye GA, Adjetey ANA, Addah W, Naandam J. Performance: characteristics of growing indigenous guinea fowl from upper east, upper west and Northern regions of Ghana. Agriculture and Biology Journal of North America. 2012;3(8):336339.
[5] Kusina NT, Saina H, Kusina JF, Lebel S. An insight into guinea fowl rearing practices and productivity by guinea fowl keepers in Zimbabwe. African Journal of Agricultural Research. 2012;7(25):3621-3625.

[6] Szalay I, Barna J, Korosine Molnar A. A gyongytyuk. Mezogazda Kiado, Budapest; 2004.

[7] Bawej M, Kokoszynski D, Bernacki Z. Evaluation of genetic similarity between white and grey varieties of Guinea fowl (Numida meleagris). Journal of Central European Agriculture. 2012;13(4):654-661.

[8] Dodu MA, Czirjak ZS. Aspects regarding the incubation process of Guinea fowl population (Numida meleagris) from Bihor county. Analele Universitatii din Oradea, Fascicula: Ecotoxicologie, Zootehnie si Tehnologii de Industrie Alimentara. 2012;11:45-50.

[9] Dong Xuan KDT, Szalay I, Duc Tien P, Minh Thu PT, Lan Phuong TN. Production Studies of a Guinea Fowl Variety of Hungarian Origin in the Tropical Regions of Vietnam. Athens Journal of Sciences. 2014;2(3):203-211. 
[10] Boko CK, Kpodekon MT, Farougou S, Dahouda M, Youssao AKI, Aplogan GL, et al. Farmer perceptions and pathological constraints in helmeted guinea fowl farming in the Borgou department in North-East Benin. African Journal of Agricultural Research. 2011;6(10):2348-2357.

[11] Moreki JC, Radikara MV. Challenges to commercialization of guinea fowl in Africa. International Journal of Science and Research. 2013;2(11):436-440.

[12] Teye GA, Gyawu P. A guide to guinea fowl production in Ghana, Department of Animal Science. University of Development Study. Tamale, Ghana; 2002.

[13] Csukas Z. Farm poultry. In: Patria Irodalmi Vallalat es Nyomdai Reszvenytarsasag, Budapest. FAO UN; 1935. .

[14] Baldy B. Principles and practical instructions of poultry breeding. In: Patria Irodalmi Vallalat es $\mathrm{Ny}-$ omdai Reszvenytarsasag, Budapest. FAO UN; 1940.

[15] Molapo SM, Webb EC. Effect of restricted feeding on the carcass characteristics of Koekoek chickens. Research Opinion in Animal and Veterinary Science. 2014;4(6):299-304.

[16] Yildrim A. Nutrition of guinea fowl breeders: A review. Journal of Animal Science Advances. 2012;2:188-193.

[17] IBM, CORP. IBM SPSS Statistics for Windows, Version 20.0. Armonk, NY, IBM Corp; 2011.

[18] Blum JC, Guillaume J, Leclercq B. Studies on the energy and protein requirements of the growing guinea fowl. British Poultry Science. 1975;16(2):157168.

[19] Adjetey NA, Atuahene CC, Adjei MB. Protein requirements for growing indigenous guinea fowl $(\mathrm{Nu}-$ mida meleagris) in the humid tropical zone of Ghana. Journal of Animal Science Advances. 2014;4(2):722731. 